\title{
Agro-industrial wastes and their utilization using solid state fermentation: a review
}

\author{
Pardeep Kumar Sadh', Surekha Duhan ${ }^{2}$ and Joginder Singh Duhan ${ }^{1 *}$
}

\begin{abstract}
Agricultural residues are rich in bioactive compounds. These residues can be used as an alternate source for the production of different products like biogas, biofuel, mushroom, and tempeh as the raw material in various researches and industries. The use of agro-industrial wastes as raw materials can help to reduce the production cost and also reduce the pollution load from the environment. Agro-industrial wastes are used for manufacturing of biofuels, enzymes, vitamins, antioxidants, animal feed, antibiotics, and other chemicals through solid state fermentation (SSF). A variety of microorganisms are used for the production of these valuable products through SSF processes. Therefore, SSF and their effect on the formation of value-added products are reviewed and discussed.
\end{abstract}

Keywords: Agro-industrial wastes, Oil cakes, Solid state fermentation, Bioactive compounds, Biotechnological approaches

\section{Background}

Agricultural-based industries produced the vast amount of residues every year. If these residues are released to the environment without proper disposal procedure that may cause to environmental pollution and harmful effect on human and animal health. Most of the agro-industrial wastes are untreated and underutilized, therefore in maximum reports it disposed of either by burning, dumping or unplanned landfilling. These untreated wastes create different problems with climate change by increasing a number of greenhouse gases. Besides this, the use of fossil fuels also contributing the effect on greenhouse gases (GHG) emission (Bos and Hamelinck 2014). So, now it is a worldwide concern to dictating the improvement of alternative cleaner and renewable bioenergy resources (Okonko et al. 2009). These wastes cause a serious disposal problem (Rodríguez-Couto 2008). For examples, the juice industries produced a huge amount of waste as peels, the coffee industry produced coffee pulp as a waste,

\footnotetext{
*Correspondence: duhanjs68@gmail.com

1 Department of Biotechnology, Chaudhary Devi Lal University, Sirsa, Haryana 125055, India

Full list of author information is available at the end of the article
}

and cereal industries produced husks. All over the world approximately 147.2 million metric tons of fiber sources are found, whereas 709.2 and 673.3 million metric tons of wheat straw residues and rice straws were estimated, respectively, in the 1990s (Belewu and Babalola 2009). As per the composition of these agro-industrial residues are concerned, they have high nutritional prospective, therefore they are getting more consideration for quality control and also categorized as agro-industrial by-products (Graminha et al. 2008).

Various studies reported that different kinds of waste such as pomegranate peels, lemon peels and green walnut husks can be used as natural antimicrobials (Adámez et al. 2012; Katalinic et al. 2010). Wastes from the organic compounds although a risk to the atmosphere, but they represent a possible source for making of mushrooms as foodstuffs and other bio-based products like bio-energy and biofertilizers. Some of the agricultural residues are used for animal food. However, such wastes contain variability in composition like high amount of proteins, sugars, and minerals. Due to high nutritional composition, these residues not described as "wastes" but considered as raw materials for other product formation and developments. The availability of these nutrients in raw 
materials offers appropriate environments for the growth of microorganisms. These microorganisms have got the ability to reuse the raw materials with the use of fermentation processes. The agro-industrial residues are used for solid support in SSF developments for making different beneficial products. It also helps for the production of fermentable sugars by reducing the production cost on the basis of food crops. Various studies were carried out to know the conversion of agricultural waste into sugars by using different microorganisms (Nguyen et al. 2010). Finally, this review described the prospective uses of agro-industrial wastes by SSF processes.

\section{Types of agro-industrial wastes}

\section{Agricultural residues}

Figure 1 shows two different types of agro-industrial wastes, i.e., agriculture residues and industrial residues. Agriculture residues can be further divided into field residues and process residues. Field residues are residues that present in the field after the process of crop harvesting. These field residues consist of leaves, stalks, seed pods, and stems, whereas the process residues are residues present even after the crop is processed into alternate valuable resource (Table 1).

These residues consist of molasses, husks, bagasse, seeds, leaves, stem, straw, stalk, shell, pulp, stubble, peel, roots, etc. and used for animal feed, soil improvement, fertilizers, manufacturing, and various other processes. Huge amount of field residues are generated and most of them are underutilized. Controlled use of field remains can enhance the proficiency of irrigation and control of erosion. In Middle East region, wheat and barley are the major crops. In addition to this, various other crops like rice, lentils, maize, chickpeas, fruits, and vegetables are also produced all over the world. Agricultural residues are differentiated on the basis of their availability as well as characteristics that can be different from other solid fuels like charcoal, wood, and char briquette (Zafar 2014).

\section{Industrial wastes}

A huge amount of organic residues and related effluents are produced every year through the food processing industries like juice, chips, meat, confectionary, and fruit industries. These organic residues can be utilized for different energy sources. As the population increases continuously, the requirement of food and their uses also increased. So, in most of the countries, different industries of food and beverage have increased remarkably in that region for fulfillment of need of food. Table 2 shows different compositions of fruit industrial wastes that constitute the different compositions of cellulose, hemicellulose, lignin, moisture, ash, carbon, nitrogen, etc. and these constituents have potential to biochemically

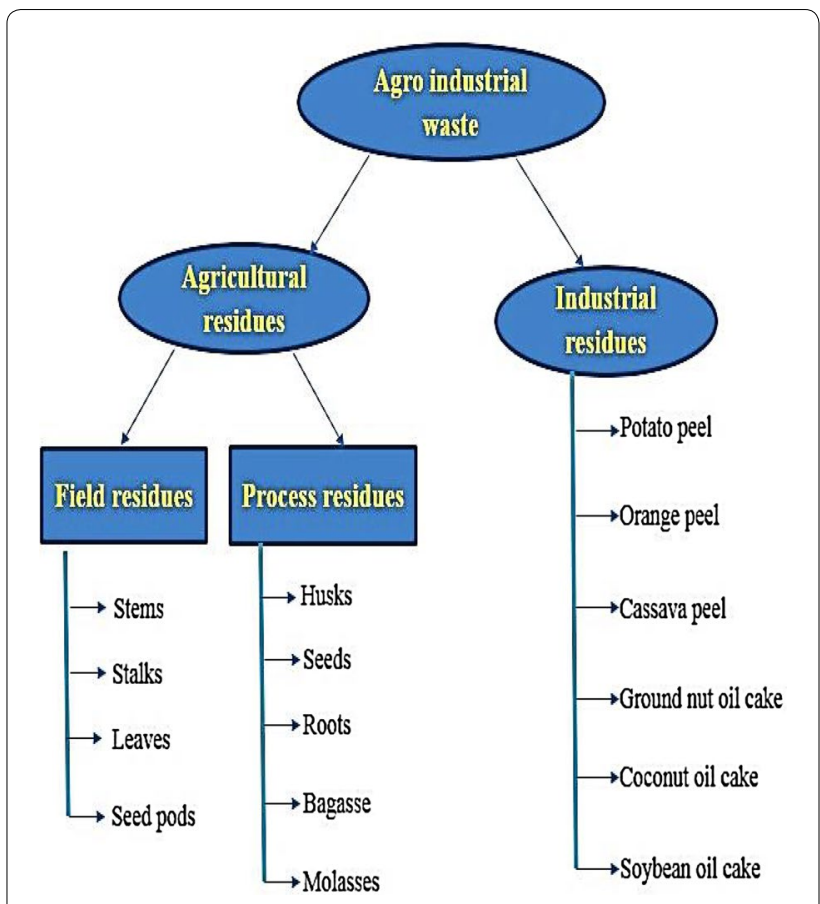

Fig. 1 Agro-industrial wastes and their types

digested to produce useful products like production of biogas, bio-ethanol, and other commercially useful examples. Approximately, $20 \%$ of the production of fruits and vegetables in India are going waste every year (Rudra et al. 2015) because in India a large amount of apple, cotton, soy bean, and wheat are produced. So as the production increased in the country, it also increased the percentage of waste produced from them. Similarly, the waste produced from food industries contains high value of BOD, COD, and other suspended solids. Most of these wastes are left unutilized or untreated, which caused adverse effect on environment as well as human and animal health but the composition of these wastes contains a large number of organic compound that produced a variety of value-added products and also reduced the cost of production as described in Table 1.

Especially in oil industries, huge amount of processed residues are produced after oil extraction from the seeds; these residues are known as oil cakes. These industries cause air, water, and solid waste pollution because these residues contain high concentration of fat, oil, grease, suspended solids, and dissolved solids. Oil cakes have variabilities based on their substrate (Table 3). Oil cake is of different types like canola oil cake ( $\mathrm{CaOC})$, sunflower oil cake (SuOC), coconut oil cake (COC), sesame oil cake (SOC), mustard oil cake (MOC), palm kernel cake $(\mathrm{PKC})$, soy bean cake (SBC), groundnut oil cake (GOC), cotton seed cake (CSC), olive oil cake (OOC), rapeseed 
Table 1 Composition of agro-industrial wastes

\begin{tabular}{|c|c|c|c|c|c|c|c|}
\hline \multirow[t]{2}{*}{ Agro-industrial wastes } & \multicolumn{6}{|c|}{ Chemical composition ( $\%$ w/w) } & \multirow[t]{2}{*}{ References } \\
\hline & Cellulose & Hemicellulose & Lignin & Ash (\%) & Total solids (\%) & Moisture (\%) & \\
\hline Sugarcane bagasse & 30.2 & 56.7 & 13.4 & 1.9 & 91.66 & 4.8 & $\begin{array}{l}\text { El-Tayeb et al. (2012) and Nigam et al. } \\
\text { (2009) }\end{array}$ \\
\hline Rice straw & 39.2 & 23.5 & 36.1 & 12.4 & 98.62 & 6.58 & El-Tayeb et al. (2012) \\
\hline Corn stalks & 61.2 & 19.3 & 6.9 & 10.8 & 97.78 & 6.40 & El-Tayeb et al. (2012) \\
\hline Sawdust & 45.1 & 28.1 & 24.2 & 1.2 & 98.54 & 1.12 & $\begin{array}{l}\text { El-Tayeb et al. (2012) and Martin et al. } \\
\text { (2012) }\end{array}$ \\
\hline Sugar beet waste & 26.3 & 18.5 & 2.5 & 4.8 & 87.5 & 12.4 & El-Tayeb et al. (2012) \\
\hline Barley straw & 33.8 & 21.9 & 13.8 & 11 & - & - & Nigam et al. (2009) \\
\hline Cotton stalks & 58.5 & 14.4 & 21.5 & 9.98 & - & 7.45 & Nigam et al. (2009) \\
\hline Oat straw & 39.4 & 27.1 & 17.5 & 8 & _- & - & Martin et al. (2012) \\
\hline Soya stalks & 34.5 & 24.8 & 19.8 & 10.39 & - & 11.84 & Motte et al. (2013) \\
\hline Sunflower stalks & 42.1 & 29.7 & 13.4 & 11.17 & - & - & Motte et al. (2013) \\
\hline Wheat straw & 32.9 & 24.0 & 8.9 & 6.7 & 95.6 & 7 & $\begin{array}{l}\text { Nigam et al. (2009) and Martin et al. } \\
\text { (2012) }\end{array}$ \\
\hline
\end{tabular}

Table 2 Composition of fruit-industrial wastes

\begin{tabular}{|c|c|c|c|c|c|c|c|c|c|}
\hline \multirow{2}{*}{$\begin{array}{l}\text { Fruit-indus- } \\
\text { trial waste }\end{array}$} & \multicolumn{9}{|c|}{ Chemical composition (\% w/w) } \\
\hline & Cellulose & $\begin{array}{l}\text { Hemi-cellu- } \\
\text { lose }\end{array}$ & Lignin & Ash & Total solids & Moisture & Total carbon & $\begin{array}{l}\text { Total nitro- } \\
\text { gen }\end{array}$ & References \\
\hline $\begin{array}{l}\text { Potato peel } \\
\text { waste }\end{array}$ & $2.2 \%$ & - & - & $7.7 \%$ & - & 9.89 & $1.3 \%$ & - & $\begin{array}{c}\text { Weshahy and } \\
\text { Rao (2012) }\end{array}$ \\
\hline Orange peel & $9.21 \%$ & $10.5 \%$ & $0.84 \%$ & $3.5 \%$ & - & 11.86 & - & - & $\begin{array}{l}\text { Rivas et al. } \\
(2008)\end{array}$ \\
\hline Coffee skin & $\begin{array}{l}23.77 \\
(\mathrm{~g} / 100 \mathrm{~g})\end{array}$ & $\begin{array}{l}16.68 \\
(\mathrm{~g} / 100 \mathrm{~g})\end{array}$ & $\begin{array}{l}28.58 \\
(\mathrm{~g} / 100 \mathrm{~g})\end{array}$ & $\begin{array}{l}5.36 \\
(\mathrm{~g} / 100 \mathrm{~g})\end{array}$ & - & - & C/N 14.41 & & $\begin{array}{l}\text { Lina et al. } \\
\quad(2014)\end{array}$ \\
\hline $\begin{array}{l}\text { Pineapple } \\
\text { peel }\end{array}$ & 18.11 & - & 1.37 & & 93.6 & 91 & 40.8 & 0.99 & $\begin{array}{l}\text { Paepatung } \\
\text { et al. (2009) }\end{array}$ \\
\hline
\end{tabular}

Table 3 Composition of oil cakes

\begin{tabular}{llllllll}
\hline Oil cakes & Dry matter & Crude protein & Crude fiber & Ash & Calcium & Phosphorus & References \\
\hline CaOC & 90 & 33.9 & 9.7 & 6.2 & 0.79 & 1.06 & Ewing (1997) \\
COC & 88.8 & 25.2 & 10.8 & 6.0 & 0.08 & 0.67 & Gohl (1970) \\
CSC & 94.3 & 40.3 & 15.7 & 6.8 & 0.31 & 0.11 & Friesecke (1970) \\
GOC & 92.6 & 49.5 & 5.3 & 4.5 & 0.11 & 0.74 & Kuo (1967) \\
MOC & 89.8 & 38.5 & 3.5 & 9.9 & 0.05 & 1.11 & Kuo (1967) \\
OOC & 85.2 & 6.3 & 40.0 & 4.2 & - & - & Maymone et al. (1961) \\
PKC & 90.8 & 18.6 & 37 & 4.5 & 0.31 & 0.85 & Owusu et al. (1970) \\
SuOC & 91 & 34.1 & 13.2 & 6.6 & 0.30 & 1.30 & Brendon (1957) \\
\hline
\end{tabular}

cake (RSC) (Ramachandran et al. 2007). These discussed agro-industrial residues are relatively cheap, containing high amount of constituents that have an unlimited prospective to be consumed as alternative substrates for fermentation.

\section{Solid state fermentation (SSF)}

Any biotechnological processes in which organisms grow on non-soluble material or solid substrates in the absence or near absence of free water is recognized as solid state fermentation (SSF) (Bhargav et al. 2008). 
Commonly used substrates in SSF are cereal grains (rice, wheat, barley, and corn), legume seeds, wheat bran, lignocellulose materials such as straws, sawdust or wood shavings, and a wide range of plant and animal materials. The compounds of these substrates are polymeric and remain insoluble or sparingly soluble in water but most of them have low cost and easily obtainable and represent a concentrated source of nutrients for microbial growth. Food preparation by fermentation is one of the oldest methods. Critical study of the literature shows that low amount of water or the absence of water in SSF offer several advantages such as easy product recovery, low cost of complete production process, smaller fermenter-size, reduced downstream processing, and also reduction of energy requirements for stirring and sterilization (Pandey 2003). For the successful process of SSF, different factors like microorganisms, solid support used, water activity, temperature, aeration, and type of fermenter used should be considered before going to start any fermentation process. The microorganisms used in SSF can occur as single pure cultures, mixed identifiable cultures or a consortium of mixed indigenous microorganisms. Some SSF processes, e.g., tempeh and oncom production, require selective growth of microorganisms such as molds that need low moisture levels to carry out fermentation with the help of extracellular enzymes secreted by fermenting microorganisms. Table 4 shows different microorganisms like fungi, yeasts, and bacteria that are used in SSF processes. Molds are frequently used in SSF for maximizing production of value added products as they grow naturally on solid substrates such as pieces of wood, seeds, stems, and roots. However, bacteria and yeasts, which require comparatively higher moisture content for efficient fermentation, can also be used for
SSF, but with a lower yield. SSF is a multistep process involving the following steps:

1. Selection of substrate.

2. Pre-treatment of substrate either by mechanical, chemical or biochemical processing to improve the availability of the bound nutrients and also to reduce the size of the components, e.g., pulverizing straw and shredding vegetable materials to optimize the physical aspects of the process. However, the cost of pre-treatment should be balanced with eventual product value.

3. Hydrolysis of primarily polymeric substrates, e.g., polysaccharides and proteins.

4. Fermentation process for utilizing hydrolysis products.

5. Downstream processing for purification and quantification of end products.

Most of the Asian and African countries used different fermented foods as a part of their diet regularly. Different forms of activated oxygen like free and non-free radicals such as superoxide anion radicals $\left(\mathrm{O}_{2}{ }^{-}\right)$, hydroxyl radicals $(\mathrm{OH})$ and $\mathrm{H}_{2} \mathrm{O}_{2}$ and singled oxygen $\left(\mathrm{O}_{2}\right)$, respectively, reported that these can lead oxidative injury to living organisms. So, these species produced a significant part in numerous diseases such as cancer, emphysema, atherosclerosis, and arthritis (Jacobs et al. 1999). SSF has been mainly employed from ancient time for processing of foods, but nowadays it is gaining a lot of attention due to the increasing use of different types of organic wastes and the larger production of value-added products (Pandey et al. 2000; Wang and Yang 2007). The search for sustainable and green processes for bioconversion of organic wastes into valuable products could substitute

Table 4 Recent studies of solid state fermentation using different microorganisms and agro-industrial wastes

\begin{tabular}{lll}
\hline Microorganisms & Solid supports & References \\
\hline $\begin{array}{l}\text { Bacteria } \\
\text { Amycolatopsis mediterranean MTCC 14 }\end{array}$ & GOC and COC & Vastrad and Neelagund (2011a, b) \\
$\begin{array}{l}\text { Xanthomonas campestries MTCC 2286 } \\
\text { Pseudomonas spp. BUP6 }\end{array}$ & Potato peel & Vidhyalakshmi et al. (2012) \\
Bacillus licheniformis MTCC 1483 & GOC, COC, SOC, and CSC & Faisal et al. (2014) \\
Fungi & Wheat straw, sugarcane bagasse, maize straw, and paddy straw & Kaur et al. (2015) \\
Aspergillus niger & Rice bran, wheat bran, black gram bran, GOC, and COC & Suganthi et al. (2011) \\
Aspergillus niger & Rice bran, wheat bran, black gram bran, and soybean & Kumar and Duhan (2011) \\
$\begin{array}{l}\text { Streptomyces spp. } \\
\text { Aspergillus oryzae } \\
\text { Rhizopus arrhizus and Mucor subtillissimus }\end{array}$ & Household kitchen wastes & Ezejiofor et al. (2012) \\
Aspergillus niger & Soybean meal (waste) & Thakur et al. (2015) \\
Aspergillus terreus & Rice bran, wheat bran, black gram bran, GOC, and COC & Nascimento et al. (2015) \\
\hline
\end{tabular}


non-renewable materials and also transform chemical processes into cleaner practices in the industrial sector that highlights the potential of SSF. The particular interest of SSF is due to its relatively simple process that uses abundant low-cost biomaterials with minimal or no pretreatment for bioconversion, less waste water generation, and the capacity for simulating similar micro-environments, favorable to microorganism growth (Singhania et al. 2009). Further, SSF has opened a new paradigm of bioconversion of organic solid wastes through the production of biologically active metabolites both at the lab and industrial scale. The application of SSF in the production of different bio-products has been widely reported including enzymes, organic acids, biofertilizers, biopesticides, biosurfactants, bioethanol, aroma compounds, animal feed, pigments, vitamins, and antibiotics. Similarly, SSF simulates natural microbiological processes such as composting and ensiling (Thomas et al. 2013). Therefore, solid state fermentation and their effect on the formation of value-added products by this process are reviewed and discussed.

\section{Substrate used for solid state fermentation}

Solid waste from different industries like food, beer and wine, agriculture, paper, textiles, detergent, and animal feed industries are used as a substrate for SSF. Substrates that remain solid also contain low moisture levels which is preferred for SSF. Figure 2 shows some of the substrate used for SSF. Several researchers used different substrates designed for their study like rice (Oryza sativa) (Sadh et al. 2017a), seim (Lablab purpureus) (Sadh et al. 2017b, c), black eyed pea (Vigna unguiculata) (Chawla et al. 2017), peanut press cake (Arachis hypogea) (Sadh et al. 2017d). Orzuaa et al. (2009) studied ten agro-industrial wastes used for their appropriateness as fungus immobilization carrier for SSF. They found that some of the waste materials have better potential for use as immobilization carrier in SSF, because they contain high water absorption capacity, and are acceptable as good growth rate of microorganisms.

\section{Utilization of agro-industrial wastes using solid state fermentation}

Agricultural wastes are used to produce large valueadded products. Figure 3 shows the schematic representation of applications from different substrates. Most of the field wastes can be used globally by the production of biofuels, biogas in place of heat, and power through various technologies. Different substrates have different compositions and used in the production of different valuable products on the basis of their composition. Some of the valuable products are described below.

\section{Bio fuel production}

Bio-fuels remain significant because they are used as substitute for fossil fuels. Previous studies revealed the production of biofuels from positive agro-industrial residues like rice straw, sweet potato waste, sawdust, potato waste, corn stalks, sugarcane bagasse, and sugar beet waste (Duhan et al. 2013; Kumar et al. 2014, 2016). In 2011, all over the world bioethanol production increased as showed by the production of 85 billion liters of bioethanol (Avci et al. 2013; Saini et al. 2014). With the help of agricultural residues, it supports in decrease the deforestation by reducing our dependence on forest woody biomass. In addition, field residues have small harvest time that reduces them extra consistently offered to bioethanol production (Limayema and Ricke 2012).

Many researches have completed the making of ethanol from materials having lignocellulosic composition (Cadoche and Lopez 1989; Bjerre et al. 1996). Najafi et al. (2009) also studied the production of bioethanol from various agricultural residues obtained from different agricultural crops. Saini et al. (2014) discussed various agricultural wastes for the production of bioethanol for second-generation. They focused on the use of lignocellulosic composition of different agro-industrial wastes. They concluded that the biofuels are useful alternatives of various fossil fuels like petrol and diesel. On the basis of their discussion and review of various approaches for biofuel production, it is clearly shown that the lignocellulosic-derived biofuels are cost effective as well as ecofriendly and alternative source of energy for upcoming future. Another study for the production of biogas by using various agriculture residues from different sources as well as two weeds, i.e., Typha angustifolia L. and Eichornia crassipes solms was carried out by Paepatung et al. (2009).

In most of the developing countries, a fast growth in population as well as their rapid development in industrialization causes the high demand of low-priced energy source by using economical agricultural residues. A large amount of required waste is available in these countries for the production of biofuels. Mushimiyimana and Tallapragada (2016) produced bioethanol from vegetable's waste by fermentation technique with the help of yeast Saccharomyces cerevisiae. They used common vegetables waste like potato peel, carrot peel, and onion peel. Bioethanol production could be the best alternate for the consumption of agricultural residues. Use of banana stem as a substrate for bioethanol production is a good alternate in India because of huge availability of banana pseudo stem as a waste. Ingale et al. (2014) produced bioethanol by using banana pseudo stem as a substrate with pre-treatment of Aspergillus ellipticus and Aspergillus fumigatus. Maiti et al. (2016) used agro-industrial 


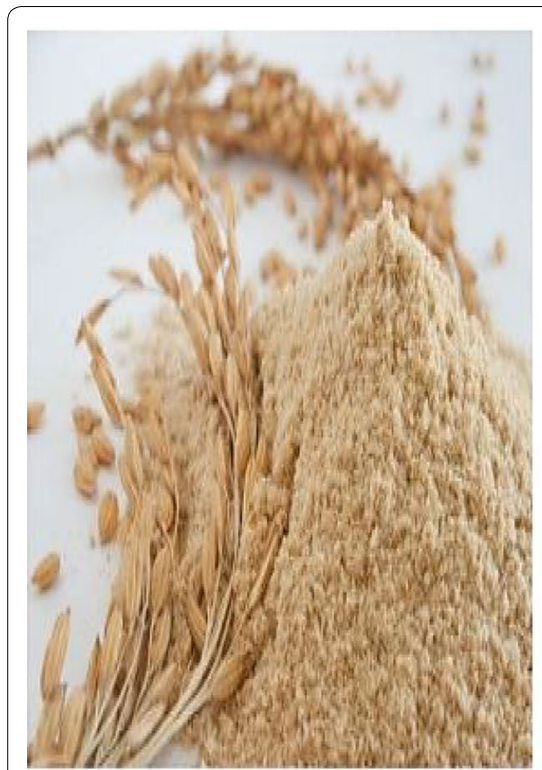

\section{Rice bran}

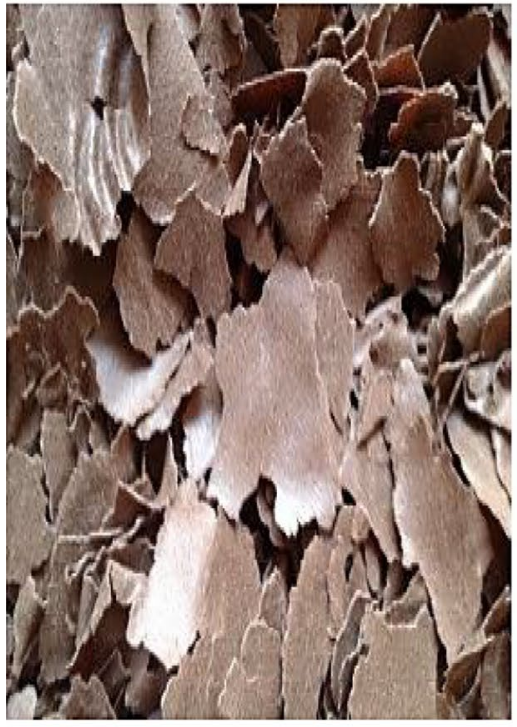

\section{Ground nut oil cake}

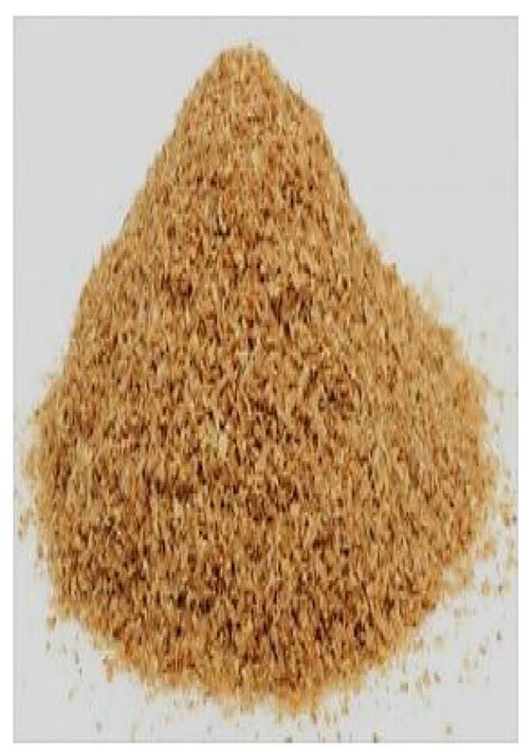

Wheat bran

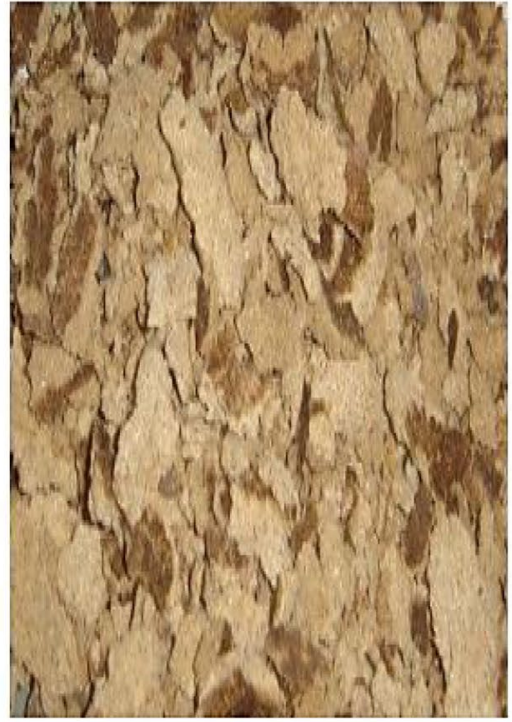

Coconut oil cake

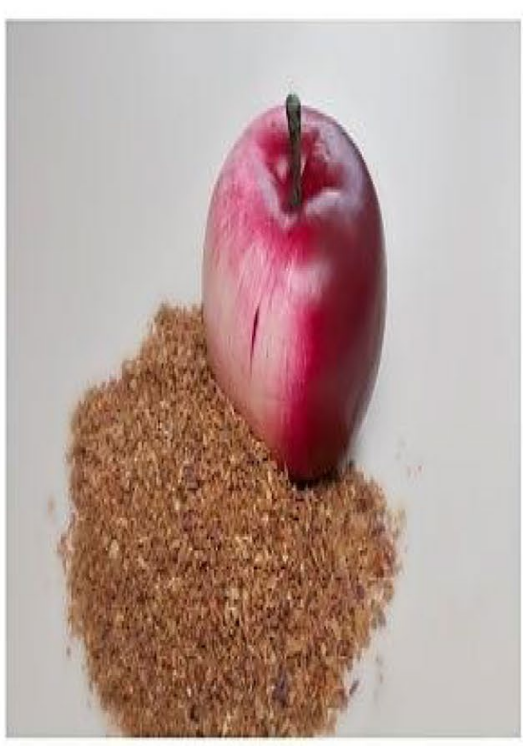

Apple pomace

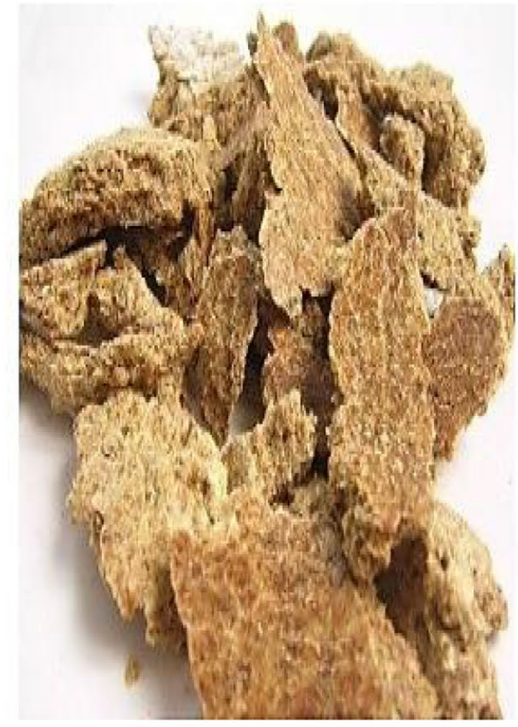

Soybean oil cake

Fig. 2 Substrates used for solid state fermentation

waste for the production of butanol by using Clostridium beijerinckii. The maximum butanol, i.e., $11.04 \mathrm{~g} / \mathrm{l}$ was produced after $96 \mathrm{~h}$ of fermentation from the agro-industrial waste starch industry wastewater (SIW). So, the use of inexpensive and ecological agricultural waste for the production of valuable biofuels is a better pathway for the fulfillment of requirement of energy through limited resources.

\section{Antioxidant properties}

Antioxidants are known as radical scavengers because they protects the human body from free radicals that 


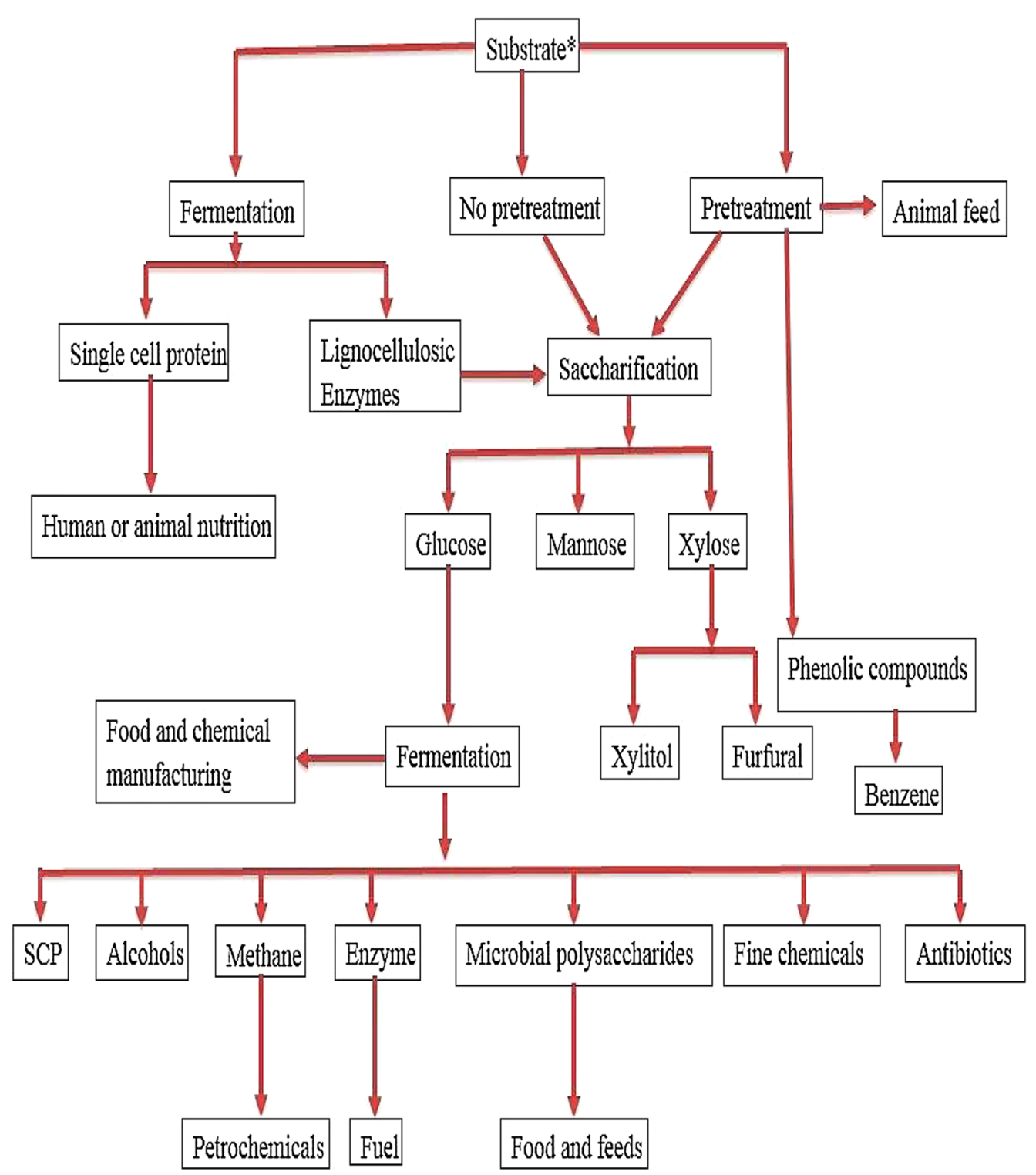

Fig. 3 Schematic representation of applications of different substrates

causes several diseases included ischemia, asthma, anemia, aging process, dementias, and arthritis. Because of the lack of knowledge about molecular composition of natural antioxidants, their use is limited. Natural antioxidants tend to be safer and they also have antiviral, anti-inflammatory, anti-cancer, anti-tumor, and hepatoprotective properties (Nigam et al. 2009).

SSF can be used to enhance the antioxidant activity of different substrates with the use of microorganisms. Antioxidant as well as anti-cancer agents was also produced with pineapple waste as a substrate for SSF. Pineapple waste included the outer peel and the central part of fruit and it contains about $50 \%$ of total fruit weight. The researchers concluded from their results that the fermented pineapple wastes have increased amount of protein content, fiber content, phenolic content, and antioxidant activities too. So they suggested that the waste from pineapple can be an alternate for new beneficial strategies (Rashad et al. 2015).

The residue of different fruits and vegetables such as fruit and vegetable peels is commonly known as a waste or no use. But many researches focused on these peels and got good results. So these wastes are considered as a valuable raw material for the production of various 
pharmaceutical products (Parashar et al. 2014). DudaChodak and Tarko (2007) investigated the antioxidant properties, total polyphenols, and tannin content of seeds and peels of some selected fruits. They found from their study that the peels of selected fruits have maximum scavenging activity and also got high polyphenol contents in the peels as compared to the selected seeds.

Orange peel extracted with different solvents exhibit variable antioxidant activities (Hegazy and Ibrahium 2012). Singh and Genitha (2014) find the maximum percentage of antioxidant activity in pomegranate peel among the lemon and orange peel. A study on peanut fractions like their skin, hull, raw, and cooked kernel was carried out by Win et al. (2011). They evaluated their properties of antioxidant and resulted that the activity of antioxidants as well as phenolic compounds of peanut skin were maximum than the other parts of peanut hull, cooked, and raw kernel. Field residues like stem, leaves, and stalks were also be used for antioxidant and antimicrobial activities. Several researchers studied the antioxidant properties of several stem extracts, leaf extracts, and fruit extracts of Argemone mexicana and Thuja orientalis (Duhan et al. 2011a, b; Saharan et al. 2012; Saharan and Duhan 2013) mixture of several medicinal plants, wheat fractions, rice (Rana et al. 2014; Duhan et al. 2015a, b, 2016) and found high antioxidant activity in extracts of these plants.

Sadh et al. (2017a, b) conducted a study to find out the effect of solid state fermentation on release of phenolics and subsequently on improvement of antioxidant activity of Lablab purpureus (seim), Oryza sativa (rice), and their combination using GRAS filamentous fungi, i.e., $A$. awamori and $A$. oryzae. They observed a significant increase in TPC level after fermentation of seed and flour with selected strains as compared to non-fermented substrate. With the increase in TPC level, the antioxidant activity of fermented samples was also increased in ethanolic extract of all the substrates with $A$. awamori and $A$. oryzae.

Sadh et al. (2017c) used a combination of substrate, i.e., rice and seim to find out the effect of solid state fermentation on release of phenolics, antioxidants, and some other functional properties. From their study, it was confirmed from the extract analysis of fermented samples that they have high phenolic, antioxidant, and functional properties than the non-fermented ones as many biochemical changes occur during fermentation, so fermentation has been used to improve or transformed the proportion of nutritive and antinutritive constituents of substrates, which affect product's properties such as biochemical or functional.

\section{Antibiotic production}

Antibiotics are substances which are produced by different microorganisms that selectively inhibit the growth or kill other microorganisms at very low concentrations (Tripathi 2008). Various agriculture wastes are used for the production of different antibiotics. Different studies were carried out by using agro-industrial waste and produced antibiotics. Ifudu (1986) used corn cobs, sawdust, and rice hulls as a raw material for the production of antibiotic, i.e., oxytetracycline. Asagbra et al. (2005) successfully produced oxytetracycline with SSF by consuming groundnut shell as a raw material with strain of Streptomyces rimosus. Yang and Swei (1996) and Tobias et al. (2012) also support the production of oxytetracycline by using agro-waste.

The cost of antibiotics production was significantly decreased by using low-cost carbon source from various agricultural residues. These residues cab be used as a remarkable substitute for the construction of neomycin and other antibiotics (Vastrad and Neelagund 2011a). Vastrad and Neelagund (2011b) studied the production of extra cellular rifamycin B by using solid state fermentation with the help of Amycolatopsis mediterranean MTCC 14 with the help of oil pressed cake as a raw material, which is also regarded as agro-industrial waste. Among the different agro-industrial wastes, two of them, i.e., coconut oil cake and ground nut shell, showed maximum antibiotic production. Supply of external energy sources was used for enhanced production of antibiotic.

\section{Oncom production}

Oncom is an indigenous fermented product from Indonesia made from several agricultural wastes. There are three types of oncom. The most well-known is that made from peanut press-cake (waste product from peanut oil processing factories). This is oncom kacang and popular in West Java (Van Veen et al. 1968; Beuchat 1986). The second type is oncom tahoo which is popular in Jakarta. It is prepared from the solid wastes of tahoo, a soya bean curd. Its preparation is similar to that for oncom kacang. The third type is made from the solid wastes of mungbean (Phaseolus radiata) starch flour (Hunkwe), and is called oncom ampas hunkwe (Steinkraus 1983).

\section{Tempeh production}

Tempeh is a type of fermented food used in most of the developing as well as developed countries. Especially in Indonesia and Malaysia tempeh is made in home individually or in small industries. The aroma and texture of fermented product, i.e., tempeh are superior as compared to the non-fermented product. Use of boiled soya beans in tempeh production showed better results as compared to 
the use of steamed or autoclaved technique. Boiled soya bean also gave a soft product as tempeh (Mak 1986).

Rhizopus strains are used for the production of tempeh as they have the abilities to degrade the raw material based on their composition. Some researchers suggested that the utilization of soya bean milk waste produced a better tempeh and it also made an alternative substrate or raw material for the production of cost effective as well as nutritionally enhanced tempeh. These studies also showed that the protein content of tempeh improved significantly after using soya bean milk wastes. Thus, soya bean milk wastes can used as a substitute of raw material for making a protein-rich human food instead of being thrown out. Various kinds of tempeh and tempeh-like products are available in Indonesia (Lim 1991).

\section{Enzyme production}

Agro-industrial wastes consist of variable composition that supports the growth of microorganisms as a result of fermentation produced different valuable enzymes. These wastes are used as a raw material. The growth rate of fungi are enhanced by use of these substrates which resulted into the conversion of lignocellulosic substrate into less complicated ones by degrading action of several enzymes. One of the important enzymes, i.e., amylase, was used in starch processing industries for degradation of polysaccharides into sugar components (Nigam and Singh 1995; Akpan et al. 1999). Kalogeris et al. (2003) studied various agricultural wastes for the production of different cellulolytic enzymes such as endoglucanase and $\beta$-glucosidase by solid state cultivation. They used thermophilic fungus strain, i.e., Thermoascus aurantiacus. They suggested that the agricultural wastes or byproducts are low-cost nutrition source for solid state cultivation to produce endoglucanase and $\beta$-glucosidase. Topakas et al. (2004) used corn cobs for the production of phenolics with solid state fermentation in addition to coupling enzymic treatment. They also studied the enzymatic production such as cinnamoyl esterase production and xylanase production. Food industries waste like peel, seed, oil cakes, and field residues such as rice bran and wheat bran are also used for amylase and Glucoamylase production by $A$. awamori in solid state fermentation was also reported (Ellaiah et al. 2002; Negi and Banerjee 2009; Suganthi et al. 2011). Likewise production of $\alpha$-amylase by Aspergillus niger MTCC 104 employing solid state fermentation has been reported (Duhan et al. 2013; Kumar et al. 2013a, b). Buenrostro et al. (2013) used four agro-industrials by-products such as sugarcane bagasse, corn cobs, candelilla stalks, and coconut husks for the production of ellagitannase, enzyme used for biodegradation of ellagic acid production and ellagitannins. They found highest production in corn cabs followed by sugarcane bagasse, coconut husks, and candelilla stalks. The production of lipase enzyme and their optimization was carried out by Oliveira et al. (2017) using oil cakes as substrate from agro-industrial waste. They used Aspergillus ibericus for the production of lipase. Highest lipase production was found in palm kernel oil cake (PKOC). Similarly, Saharan et al. (2017) carried out a study to know the effect of fermentation on phenolics, flavonoids, and free radical scavenging activity of commonly used cereals and also studied the role of $\alpha$-amylase, xylanase, and $\beta$-glucosidase enzymes in release of polyphenols and antioxidants during solid state fermentation of cereals. Results showed a positive correlation between polyphenols and enzyme activities. Similarly, various enzymatic assays were performed such as $\alpha$-amylase, xylanase, $\beta$-glucosidase, and lipase during fermentation of peanut press cake with $A$. oryzae, resulted a significant enhancement of enzyme activities in all assays (Sadh et al. 2017e). Table 5 shows several studies that have been conducted on construction of various enzymes with the use of agroindustrial residues.

Table 5 Studies on production of enzymes by microorganisms using agro-industrial wastes

\begin{tabular}{|c|c|c|c|}
\hline Substrates & Enzymes & Microorganisms & Source \\
\hline Papaya waste & a-Amylase & A. niger & Sharanappa et al. (2011) \\
\hline Groundnut oil cake (GOC) & Lipase & C.rugosa & Rekha et al. (2012) \\
\hline Wheat bran and orange peel & Pectin methyl esterase & P. notatum & Gayen and Ghosh (2011) \\
\hline Linseed oil cake (LOC) & Lipase & P. aeruginosa & Dharmendra (2012) \\
\hline Orange peel & a-Amylase & A. niger & Sindiri et al. (2013) \\
\hline Coconut oil cake (COC) & a-Amylase & A. oryzae & Ramachandran et al. (2004) \\
\hline Rice bran & a-Amylase & Bacillus sp. & Sodhi et al. (2005) \\
\hline Corn bran & a-Amylase & Bacillus sp. & Sodhi et al. (2005) \\
\hline Rice bran, wheat bran, black gram bran, and soybean & a-Amylase & A. niger & Akpan et al. (1999) \\
\hline Fruits peel waste & Invertase & A. niger & Mehta and Duhan (2014) \\
\hline
\end{tabular}




\section{Mushroom production}

A mushroom constitutes unique fruiting body and can be epigeous or hypogenous in origin. Mushroom used either as a protein-rich food or used as a bioremediation tool. The agro-industrial lingo-cellulosic wastes and residues are used as a bio-conservation for the cultivation of edible fungi in a controlled way. The environmentrelated problem with agro-based residues can be solved by the production of mushroom in a controlled manner by using these wastes as a raw material. Production of mushroom worked as a noticeable method of biotechnology for the valorization of agro-industrial waste. Production of mushroom also showed its strength towards ecological as well as economical points by the transformation of agro-based residues using various microorganisms (Chang 2006; Randive 2012). Mushroom production is a good example of recovery of food proteins by using biological process in a small or large scale from lignocellulosic materials (Chiu and Moore 2001).

Jonathan and Babalola (2013) studied 16 diverse agroindustrial wastes for cultivation of edible mushroom, i.e., Pleurotus tuber-regium. The species of Pleurotus is generally known as oyster mushrooms. Utilization of such agro-industrial residues for cultivation of mushroom resulted into modification to edible protein in relations of mushroom fruit bodies (Lakshmi and Sornaraj 2014). Banana stalks and Bahia grass were also utilized for Pleurotus sajor-caju production (Siqueira et al. 2011). The results for production of Pleurotus by using banana stalks and bahia grass as substrate suggested that no other supplement such as wheat bran and rice bran were needed for successfully production of the mushroom.

Edible oyster mushrooms are excellent delicacies in many regions of the world (Jonathan et al. 2008). Randive (2012) cultivated and studied the growth as well as nutrient composition of oyster mushroom by using various agro-based residues as a substrate. He determined the proximate composition of mushroom such as protein content, fiber content, ash content, lipid content, moisture content and carbohydrate content. From the results, he suggested that even the same genus mushroom have different nutritional compositions as compared to each other. However, all the produced mushroom was rich in protein contents. So, in case of protein deficiency, he suggested to take oyster mushroom in diet. Oyster mushroom can also be helpful against heart disease and diabetes. In Southern America, a study was carried out for the cultivation of oyster mushroom with the use of coffee husks as a substrate (Murthy and Manonmani 2008). Babu and subhasree (2010) cultivated the two Pleurotus mushroom, i.e., Pleurotus eous and Pleurotus platypus by using agro-industrial waste. They found increased amount of protein, lipid, carbohydrate, etc. with the use of paddy straw as a substrate in their study. So, they also suggested the take of edible oyster mushroom for high protein content and also suggested the use of paddy straw as a substrate for the successful production of mushroom (Akinyele et al. 2012; Kumhomkul and Panich 2013).

\section{Other approaches using SSF}

Apart from these studies, some other useful approaches by SSF are also discussed here (Fig. 4).

\section{Single cell protein production}

Mondal et al. (2012) studied the production of singlecell protein (SCP) from fruit wastes. They used cucumber and orange peels as the substrate for the production of SCP with the help of S. cerevisiae by using submerged fermentation. They found that cucumber peel produced larger amount of protein as compared to the orange peels. So it was suggested that these fruit wastes can convert into SCP by using suitable microbes. The products obtained from the bioconversion of agro-industry wastes are economical and nutritionally contained high content of protein.

\section{Production of poly(3-hydroxybutyric acid)}

Citrus fruits are consumed all over the world for different industrial purposes like fruit juice, and jams. So these types of industries also produced a colossal amount of waste as a peel residue or in other form but these citrus wastes can be used in fermentation as they contain large amount of carbohydrates. Sukan et al. (2014) used orange peel waste for the production of Poly (3-HB). Their results showed that orange peel has a rich and unutilized agro-industrial waste. They reported first time the production of Poly (3HB) using orange peel as a single carbon source with a very simple pre-treatment method.

\section{Biosurfactant production}

Most of the bacterial species are found in oil contaminated sites and these bacterial species have the ability to produce useful or beneficial products for mankind. Saravanan and Vijayakumar (2014) isolate a bacterial strain i.e., Pseudomonas aeruginosa PB3A from oil-contaminated site. They used the strain for the production of biosurfactant by using agro-waste such as castor oil, sunflower oil, barley bran, peanut cake, and rice bran. They used these wastes as a rich alternative carbon source for the production of biosurfactant by using isolated $P$. aeruginosa strain.

\section{Xanthan production}

Xanthan is a type of exopolysaccharides, produced from Xanthomonas species. Xanthan is used as food additives. 


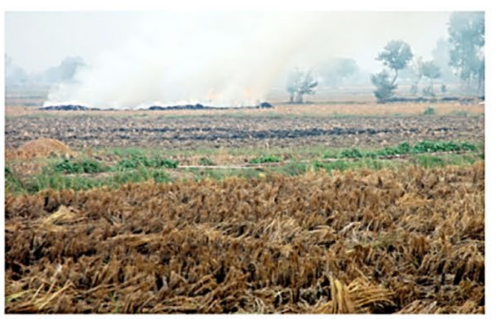

RICE STRAW

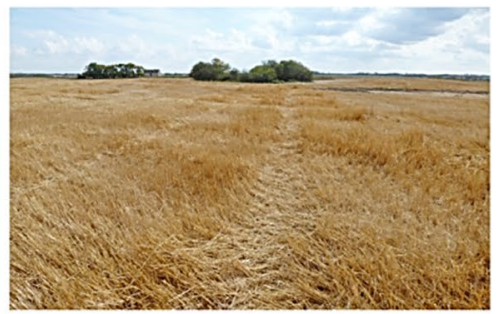

WHEAT STRAW

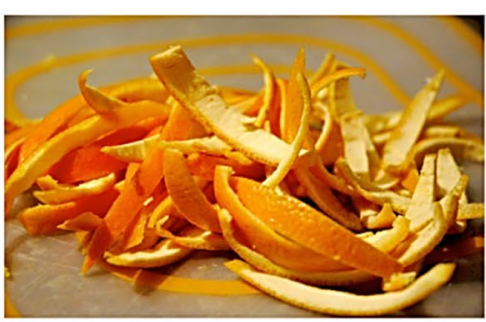

ORANGE PEEL

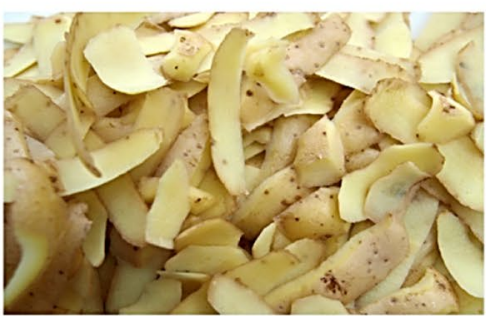

POTATO PEEL

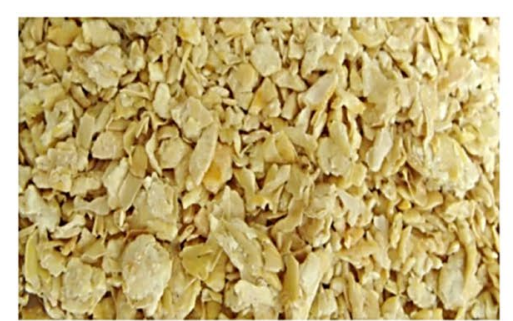

SOYABEAN OIL CAKE

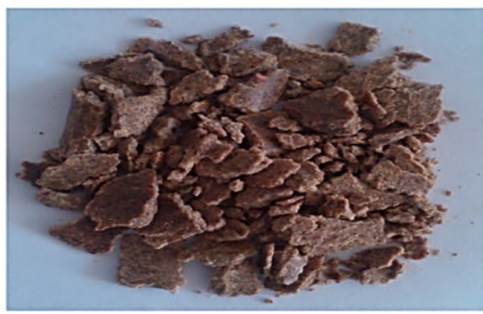

PEANUT OIL CAKE

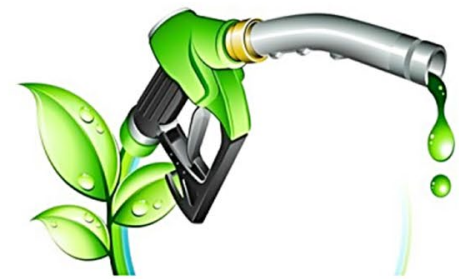

BIOFUELS

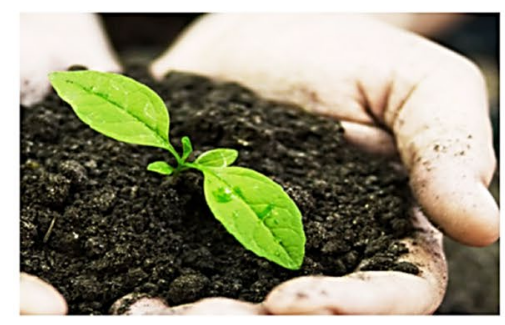

BIOFERTILIZER

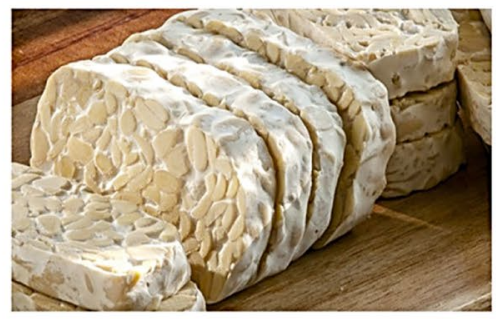

TEMPEH

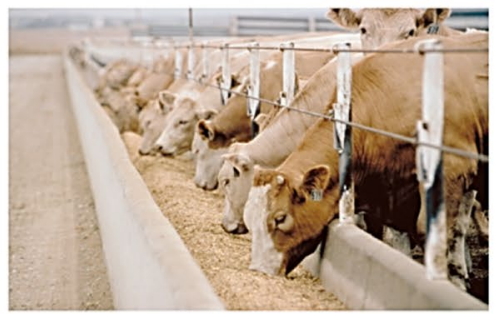

ANIMAL FEED

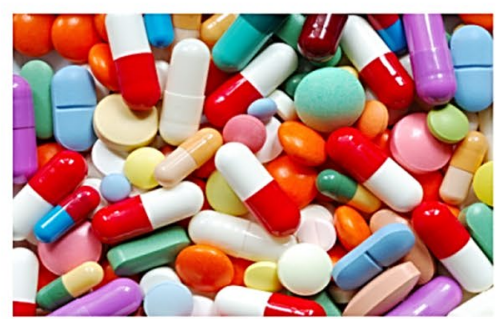

ANTIBIOTICS

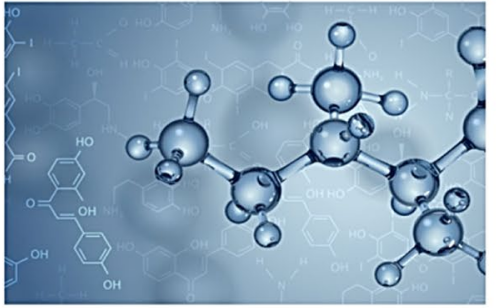

CHEMICALS

Fig. 4 Applications of agro-industrial wastes 
So, the production of xanthan from agro-waste is a valuable approach as cost-effective product. Vidhyalakshmi et al. (2012) carried out a study for the production of xanthan from different agro-industrial residues. They produced xanthan by SSF with the help of $X$. campestries, $X$. citri, $X$. oryzae, and $X$. musacearum. The highest xanthan was produced by $X$. citri on potato peels, i.e., $2.90 \mathrm{~g} / 50 \mathrm{~g}$ followed by $2.87 \mathrm{~g} / 50 \mathrm{~g}, 1.50 \mathrm{~g} / 50 \mathrm{~g}$, and $0.50 \mathrm{~g} / 50 \mathrm{~g}$ by $X$. campestries, $X$. oryzae, and $X$. musacearum, respectively.

\section{Immobilization carrier production}

Orzuaa et al. (2009) studied ten agro-industrial wastes including lime peel, orange peel, apple pomace, pistachio shell, wheat bran, coconut husk, etc. They studied the appropriateness of various agro-industrial wastes as immobilization carrier for SSF. Before continuing the study, they characterized the agro-industrial wastes with physio-chemical treatment. Finally, Orzuaa et al. (2009) concluded that out of ten agro-industrial wastes, four of them including Citrus aurantifolia, Malus domestica, Citrus sinensis, and Cocos nucifera have excessive potential as immobilization carrier for SSF. These agro-industrial wastes can be used further for economical advantage as well as environmental-friendly way for waste management.

\section{Conclusion and future prospectus}

Agro-industrial wastes or residues are rich in nutrient composition and bioactive compounds. Such wastes comprise variability in composition such as sugars, minerals, and proteins; consequently, they should be considered as "raw material" instead of "wastes" for other industrial processes. The occurrence of such nutrients in these residues offers suitable conditions for the prolific growth of microorganisms. The microorganisms have potential to reuse the waste as raw materials for their growth through fermentation processes. The agro-industrial wastes can be used as solid support in SSF processes for the production of a range of significant beneficial compounds. The use of agricultural and agro-basedindustry wastes as raw materials can help to reduce the production cost and contributed in recycling of waste as well to make the environment eco-friendly.

\footnotetext{
Abbreviations

SSF: solid state fermentation; OCs: oil cakes; MTCC: microbial type culture collection; GRAS: generally regarded as safe; SCP: single cell protein; CaOC: canola oil cake; SuOC: sunflower oil cake; COC: coconut oil cake; SOC: sesame oil cake; MOC: mustard oil cake; PKC: palm kernel cake; SBC: soy bean cake; GOC: groundnut oil cake; CSC: cotton seed cake; OOC: olive oil cake; RSC: rapeseed cake.
}

\section{Authors' contributions}

PKS prepared the framework of the review article. SD and JSD proofread and corrected the manuscript. All authors read and approved the final manuscript.

\section{Author details}

1 Department of Biotechnology, Chaudhary Devi Lal University, Sirsa, Haryana

125055, India. ${ }^{2}$ Department of Botany, GNC, Sirsa, Haryana 125055, India.

\section{Acknowledgements}

The support by Department of Biotechnology, Chaudhary Devi Lal University, Sirsa, Haryana, India is gratefully acknowledged.

\section{Competing interests}

The authors declare that they have no competing interests.

Consent for publication

All authors read and approved the manuscript for publication.

Ethics approval and consent to participate

Not applicable.

Funding

There is no funding source.

\section{Publisher's Note}

Springer Nature remains neutral with regard to jurisdictional claims in published maps and institutional affiliations.

Received: 14 October 2017 Accepted: 22 December 2017

Published online: 02 January 2018

\section{References}

Adámez JD, Samino EG, Sánchez EV, González GD (2012) In vitro estimation of the antibacterial activity and antioxidant capacity of aqueous extracts from grape-seeds (Vitis vinifera L.). Food Control 24:136-141

Akinyele JB, Fakoya S, Adetuyi CF (2012) Anti-growth factors associated with Pleurotus ostreatus in a submerged liquid fermentation. Malays J Microbiol 8:135-140

Akpan I, Bankole MO, Adesemowo AM, Latunde DG (1999) Production of amylase by $A$. niger in a cheap solid medium using rice bran and agricultural materials. Trop Sci 39:77-79

Asagbra AE, Sani Al, Oyewole OB (2005) Solid state fermentation production of tetracycline by Streptomyces strains using some agricultural wastes as substrate. World J Microbiol Biotechnol 21:107-114

Avci A, Saha BC, Dien BS, Kennedy GJ, Cotta MA (2013) Response surface optimization of corn stover pretreatment using dilute phosphoric acid for enzymatic hydrolysis and ethanol production. Biores Technol 130:603-612

Babu PD, Subhasree RS (2010) Valuing the suitable agro-industrial wastes for cultivation of P. platypus and P. eous. Adv Biol Res 4:207-210

Belewu MA, Babalola FT (2009) Nutrient enrichment of some waste agricultural residues after solid state fermentation using Rhizopus oligosporus. J Appl Biosci 13:695-699

Beuchat LR (1986) Oncom (fermented peanut presscake). In: Reddy NR, Pierson MD, Salunkhe DK (eds) Legume-based fermented foods. CRC Press, Boca Raton, pp 135-144

Bhargav S, Panda BP, Ali M, Javed S (2008) Solid-state fermentation: an overview. Chem Biochem Eng 22(1):49-70

Bjerre $A B$, Olesen AB, Fernqvist $T$ (1996) Pretreatment of wheat straw using combined wet oxidation and alkaline hydrolysis resulting in convertible cellulose and hemicellulose. Biotechnol Bioeng 49:568-577

Bos A, Hamelinck C (2014) Greenhouse gas impact of marginal fossil fuel use. Project number: BIENL14773 2014

Brendon RM (1957) Uganda Protectorate. Department of Veterinary Services and Animal Industry. Occasional Bulletin No. 1

Buenrostro J, Ascacio A, Sepulveda L, De la Cruz R, Prado-Barragan A, AguilarGonzalez MA, Rodriguez R, Aguilar CN (2013) Potential use of different agro-industrial by products as supports for fungal ellagitannase production under solid state fermentation. Food Bioprod Process. https:// doi.org/10.1016/j.fbp.2013.08.010 
Cadoche L, Lopez GD (1989) Assessment of size reduction as a preliminary step in the production of ethanol from lignocellulosic wastes. Biol Waste 30:153-157

Chang ST (2006) The World Mushroom Industry: trends and technological development. Intern J Med Mushrooms 8:297-314

Chawla P, Bhandari L, Sadh PK, Kaushik R (2017) Impact of solid state fermentation (Aspergillus oryzae) on functional properties and mineral bioavailability of black eyed pea (Vigna unguiculata) seed flour. Cereal Chem 94(3):437-442

Chiu SW, Moore D (2001) Threats to biodiversity caused by the traditional mushroom cultivation in China. In: Moore D, Nauta M, Rotheroe M (eds). Fungal conservation. The 21st Century issue Cambridge, pp 111-119

Dharmendra KP (2012) Production of lipase utilizing linseed oilcake as fermentation substrate. Intern J Sci Environ Technol 1:135-143

Duda-Chodak A, Tarko T (2007) Antioxidant properties of different fruit seeds and peels. Acta Sci Pol Technol Aliment 6:29-36

Duhan JS, Bhardwaj M, Surekha (2011a) Free radical-scavenging and antimutagenic potential of acetone, chloroform and methanol extracts of leaves of Argemone maxicana. Intern J Pharma Biosci 2(1):B455-B464

Duhan JS, Bhardwaj M, Surekha (2011 b) Free radical-scavenging and antimutagenic potential of acetone, chloroform and methanol extracts of fruit of Argemone maxicana. Afr J Biotechnol 10:8654-8661

Duhan JS, Kumar A, Tanwar SK (2013) Bioethanol production from starchy part of tuberous plant (potato) using Saccharomyces cerevisiae MTCC-170. Afr J Microbiol Res 7:5253-5260

Duhan JS, Mehta K, Sadh PK, Saharan P, Surekha (2015a) Bio-enrichment of phenolics and free radicals scavenging activity of wheat (WH-711) fractions by solid state fermentation with Aspergillus oryzae. Afr J Biochem Res 10:12-19

Duhan JS, Rana A, Sadh PK, Saharan P, Surekha (2015b) Antimicrobial and free radical scavenging activity of selective medicinal plants combination. World J Pharm Pharm Sci 4:1202-1216

Duhan JS, Bhardwaj M, Sadh PK, Surekha (2016) In vitro antimicrobial efficacy, free radical scavenging activity and antimutagenic potential of stem extract of Capparis decidua. World J Pharma Pharm Sci 5(10):786-803

Ellaiah K, Adinarayana Y, Bhavani P, Padmaja B, Srinivasulu (2002) Optimization of process parameters for glucoamylase production under solid-state fermentation by a new isolated Aspergillus species. Process Biochem 38:615-620

El-Tayeb TS, Abdelhafez AA, Ali SH, Ramadan EM (2012) Effect of acid hydrolysis and fungal biotreatment on agro-industrial wastes for obtainment of free sugars for bioethanol production. Braz J Microbiol 43(4):1523-1535

Ewing WN (1997) The feeds directory. Context Publications, Leicestershire England

Ezejiofor TIN, Duru Cl, Asagbra AE, Ezejiofor AN, Orisakwe OE, Afonne JO, Obi E (2012) Waste to wealth: production of oxytetracycline using streptomyces species from household kitchen wastes of agricultural produce. Afr J Biotechnol 11·10115-10124

Faisal PA, Hareesh ES, Priji P, Unni KN, Sajith S, Sreedevi S, Josh MS, Benjamin S (2014) Optimization of parameters for the production of lipase from Pseudomonas sp. BUP6 by solid state fermentation. Adv Enzyme Res 2:125-133

Friesecke HK (1970) Final report. UNDP/SF Project No. 150 (IRQ/6)

Gayen S, Ghosh U (2011) Pectin methyl esterase production from mixed agrowastes by Penicillium notatum NCIM 923 in solid state fermentation. J Bioremed Biodegrad 2:119

Gohl BI (1970) Animal feed from local products and by-products in the British Caribbean. Rome, FAO. AGA/Misc/70/25

Graminha EBN, Goncalves AZL, Pirota RDPB, Balsalobre MAA, Silva R, Gomes E (2008) Enzyme production by solid-state fermentation: application to animal nutrition. Anim Feed Sci Technol 144:1-22

Hegazy AE, Ibrahium MI (2012) Antioxidant activities of orange peel extracts. World Appl Sci J 18:684-688

Ifudu ND (1986) Indigenous resources for antibiotic production, Nov/Dec. edn Expansion Today Nigeria. African University Press Ltd, pp 52-53

Ingale S, Joshi SJ, Gupte A (2014) Production of bioethanol using agricultural waste: banana pseudo stem. Braz J Microbiol 45(3):885-892

Jacobs DR, Meyer KA, Kushi LH, Folsom AR (1999) Is whole grain intake associated with reduced total and cause-specific death rates in older women? The lowa women's health study. Am J Pub Health 89:322-329
Jonathan SG, Babalola B (2013) Utilization of agro-industrial wastes for the cultivation of Pleurotus tuber-regium (Fries) Singer. Nigerian edible mushroom

Jonathan SG, Fasidi IO, Ajayi AO, Adegeye A (2008) Biodegradation of Nigerian wood wastes by Pleurotus tuber-regium (Fries) Singer. Bioresour Technol 99:807-811

Kalogeris E, Christakopoulos P, Katapodis P, Alexiou A, Vlachou S, Kekos D, Macris BJ (2003) Production and characterization of cellulolytic enzymes from the thermophilic fungus Thermoascus aurantiacus under solid state cultivation of agricultural wastes. Process Biochem 38:1099-1104

Katalinic V, Mozina SS, Skroza D, Generalic I, Abramovic H, Milos M, Ljubenkov I, Piskernik S, Pezo I, Terpinc P, Boban M (2010) Polyphenolic profile, antioxidant properties and antimicrobial activity of grape skin extracts of 14 Vitis vinifera varieties grown in dalmatia (Croatia). Food Chem 119:715-723

Kaur PS, Kaur S, Kaur H, Sharma A, Raj P, Panwar S (2015) Solid substrate fermentation using agro industrial waste: new approach for amylase production by Bacillus licheniformis. Intern J Curr Microbiol Appl Sci 4:712-717

Kumar A, Duhan JS (2011) Production and characterization of amylase enzyme isolated from Aspergillus niger MTCC-104 employing solid state fermentation. Intern J Pharam Biol Sci 2:B250-B258

Kumar A, Duhan JS, Tanwar SK (2013a) Screening of Aspergillus spp. for extra cellular a-amylase activity. In: Khanna AK, Chopra G, Matta V, Singh, Bhutiani R (eds) Impact of global climate change on earth ecosystem. Biotech Books, New Delhi 205-214

Kumar A, Duhan JS, Tanwar SK (2013b) Screening of Aspergillus spp. for extra cellular a-amylase activity. In: Khanna AK, Chopra G, Matta V, Matta $V$, Singh, Bhutiani R (eds) Impact of global climate change on earth ecosystem. Biotech Books, New Delhi, pp 205-214

Kumar A, Duhan JS, Gahlawat SK, Surekha (2014) Production of ethanol from tuberous plant (sweet potato) using Saccharomyces cerevisiae MTCC170. Afr J Biotechnol 13(28):2874-2883

Kumar A, Sadh PK, Surekha, Duhan JS (2016) Bio-ethanol production from sweet potato using co-culture of saccharolytic molds (Aspergillus spp.) and Saccharomyces cerevisiae MTCC170. J Adv Biotechnol 6(1):822-827

Kumhomkul T, Panich T (2013) Lead accumulation in the straw mushroom, Volvariella volvacea, from lead contaminated rice straw and stubble. Bull Environ Contam Toxicol 91:231-234

Kuo LH (1967) Animal feeding stu Vs compositional data of feeds and concentrates (part 3). Malays Agric J 46:63-70

Lakshmi S, Sornaraj R (2014) Utilization of see food processing waste for cultivation of the edible mushroom Pleurotus flabellatus. Afr J Biotechnol 17:1779-1785

Lim G (1991) Indigenous fermented foods in south east asia. ASEAN Food J 6(3):83-101

Limayema A, Ricke SC (2012) Lignocellulosic biomass for bioethanol production: current perspectives, potential issues and future prospects. Prog Energy Combust Sci 38:449-467

Lina F, Ballesteros JA, Teixeira SI, Mussatto (2014) Chemical, functional, and structural properties of spent coffee grounds and coffee silverskin. Food Bioprocess Technol 7:3493-3503

Mahalakshmi N, Jayalakshmi S (2016) Amylase, cellulase and xylanase production from a novel bacterial isolate Achromobacter xylosoxidans isolated from marine environment. Intern J Adv Res Biol Sci 3:230-233

Maiti S, Sarma SJ, Brar SK, Le Bihan Y, Drogui P, Buelna G, Verma M (2016) Agro-industrial wastes as feed stock for sustainable bio-production of butanol by Clostridium beijerinckii. Food Bioprod Process. https://doi. org/10.1016/j.fbp.2016.01.002

Mak ML (1986) Tempeh production from soybean milk wastes and soybeans by various Rhizopus strains. B.Sc. Hons thesis, Singapore National University Singapore

Martin JGP, Porto E, Correa CB, Alencar SM, Gloria EM, Cabral ISR, Aquino LM (2012) Antimicrobial potential and chemical composition of agroindustrial wastes. J Nat Prod 5:27-36

Maymone B, Battaglini A, Tiberio M (1961) Ricerche sul valore nutritive della sansa d'olive. Alimentazione Animale Alimentazione Animale 5:219-250

Mehta K, Duhan JS (2014) Production of invertase from Aspergillus niger using fruit peel waste as a substrate. Intern J Pharm Biol Sci 5(2):B353-B360 
Mondal AK, Sengupta S, Bhowal J, Bhattacharya DK (2012) Utilization of fruit wastes in producing single cell protein. Intern J Sci Environ Technol 1(5):430-438

Motte JC, Trably E, Escudié R, Hamelin J, Steyer JP, Bernet N, Delgenes JP, Dumas C (2013) Total solids content: a key parameter of metabolic pathways in dry anaerobic digestion. Biotechnol Biofuels 6:164

Murthy PS, Manonmani HK (2008) Bioconversion of coffee industry wastes with white rot fungus Pleurotus florida. Res J Environ Sci 2:145-150

Mushimiyimana I, Tallapragada P (2016) Bioethanol production from agro wastes by acid hydrolysis and fermentation process. J Sci Ind Res 75:383-388

Najafi G, Ghobadian B, Tavakoli T, Yusaf T (2009) Potential of bioethanol production from agricultural wastes in Iran. Renew Sustain Energy Rev 13:1418-1427

Nascimento TP, Sales AE, Camila CS, Romero RMP, Takaki GMC, Teixeira JAC, Porto TS, Porto ALF (2015) Production and characterization of new fibrinolytic protease from Mucor subtillissimus UCP 1262 in solid-state fermentation. Adv Enzyme Res 3:81-91

Negi S, Banerjee R (2009) Optimization of extraction and purification of glucoamylase produced by A. awamori in solid state fermentation. Biotechnol Bioprocess Eng 14:60-66

Nguyen TAD, Kim KR, Han SJ, Cho HY, Kim JW, Park SM, Sim SJ (2010) Pretreatment of rice straw with ammonia and ionic liquid for lignocelluloses conversion to fermentable sugars. Bioresour Technol 101:7432-7438

Nigam P, Singh D (1995) Enzymes and microbial enzymes involved in starch processing enzymes. Enzyme Microbial Technol 17:770-778

Nigam PS, Gupta N, Anthwal A (2009) Pre-treatment of agro-industrial residues. In: Nigam PS, Pandey A (eds) Biotechnology for agro-industrial residues utilization. Springer, Heidelberg, pp 13-33

Okonko IO, Adeola OT, Aloysius FE, Damilola AO, Adewale OA (2009) Utilization of food wastes for sustainable development. Electr J Environ Agric Food Chem 8(4):263-286

Oliveira F, Carlos ES, Peclat Veronica ROL, Salgado JM, Bernardo DR, Maria AZC, Armando V, Isabel B (2017) Optimization of lipase production by Aspergillus ibericus from oil cakes and its application in esterification reactions. Food Bioprod Process. https://doi.org/10.1016/j.fbp.2017.01.007

Orzuaa MC, Mussattob SI, Contreras EJC, Rodrigueza R, Garzaa HTA, Aguilara CN (2009) Exploitation of agro-industrial wastes as immobilization carrier for solid-state fermentation. Ind Crops Prod 30:24-27

Owusu K, Christensen DA, Owen BD (1970) Nutritive value of some Ghanian feed-stu Vs. Can J Anim Sci 50:1-14

Paepatung N, Nopharatana A, Songkasiri W (2009) Bio-methane potential of biological solid materials and agricultural wastes. Asian J Energy Env 10:19-27

Pandey A (2003) Solid state fermentation. Biochem Eng J 13:81-84

Pandey A, Soccol CR, Mitchell D (2000) New developments in solid state fermentation: I-bioprocesses and products. Process Biochem 35:1153-1169

Parashar S, Sharma H, Garg M (2014) Antimicrobial and antioxidant activities of fruits and vegetable peels: a review. J Pharmcogn Phytochem 3:160-164

Rahman KHA, Yusof SJHM, Zakaria Z (2016) Bioproteins production from palm oil agro-industrial wastes by Aspergillus terreus UniMAP AA-1 Pertanika. J Trop Agric Sci 39:29-39

Ramachandran S, Patel AK, Nampoothiri KM, Francis F, Nagy V, Szakacs G, Pandey A (2004) Coconut oil cake - a potential raw material for the production of a-amylase. Bioresour Technol 93:169-174

Ramachandran S, Singh SK, Larroche C, Soccol CR, Pandey A (2007) A oil cakes and their biotechnological applications - a review. Bioresour Technol 98.2000-2009

Rana A, Saharan P, Sadh PK, Surekha, Duhan JS (2014) Free radical scavenging and antimicrobial potential of mixture of selective medicinal plants. Asian J Pharm Clinical Res 7:27-32

Randive SD (2012) Cultivation and study of growth of oyster mushroom on different agricultural waste substrate and its nutrient analysis. Adv Appl Sci Res 3:1938-1949

Rashad MM, Mahmoud AE, Ali MM, Nooman MU, Al-Kashef AS (2015) Antioxidant and anticancer agents produced from pineapple waste by solid state fermentation. Intern J Toxicol Pharmacol Res 7(6):287-296
Rekha KSS, Lakshmi C, Devi SV, Kumar MS (2012) Production and optimization of lipase from Candida rugosa using groundnut oilcake under solid state fermentation. Intern J Res Eng Technol 1:571-577

Rivas B, Torrado A, Torre P, Converti A, Domínguez JM (2008) Submerged citric acid fermentation on orange peel autohydrolysate. J Agric Food Chem 56:2380-2387

Rodríguez-Couto S (2008) Exploitation of biological wastes for the production of value-added products under solid-state fermentation conditions. Biotechnol J 3:859-870

Rudra SG, Nishad J, Jakhar N, Kaur C (2015) Food industry waste: mine of nutraceuticals. Intern J Sci Environ Technol 4(1):205-229

Sadh PK, Chawla P, Bhandari L, Kaushik R, Duhan JS (2017a) In vitro assessment of bio-augmented minerals from peanut oil cakes fermented by Aspergillus oryzae through Caco-2 cells. J Food Sci Techol 54:3640-3649. https://doi.org/10.1007/s13197-017-2825-z

Sadh PK, Duhan JS, Surekha, Saharan P (2017b) Bio-augmentation of phenolics and antioxidant activity of Oryza sativa by solid state fermentation with Aspergillus spp. Intern Food Res J 24(3):1160-1166

Sadh PK, Saharan P, Duhan JS (2017c) Bio-augmentation of antioxidants and phenolic content of Lablab purpureus by solid state fermentation with GRAS filamentous fungi. Resour Effic Technol 3:285-292. https://doi. org/10.1016/j.reffit.2016.12.007

Sadh PK, Saharan P, Duhan S, Duhan JS (2017d) Bio-enrichment of phenolics and antioxidant activity of combination of Oryza sativa and Lablab purpureus fermented with GRAS filamentous fungi. Resour Effic Technol 3:347-352. https://doi.org/10.1016/j.reffit.2017.02.008

Sadh PK, Chawla P, Bhandari L, Duhan JS (2017e) Bio-enrichment of functional properties of peanut oil cakes by solid state fermentation using Aspergillus oryzae. J Food Meas Character. https://doi.org/10.1007/ S1 1694-017-9675-2

Saharan P, Duhan JS (2013) Studies on antioxidant activity, total phenolic and flavanoid contents of leaf extracts of Thuja orientalis. In: Khanna DR, Chopra AK, Matta G, Singh V, Bhutiani R (eds) Impact of global climate change on earth ecosystem. Biotech Books, New Delhi, pp 193-203. ISBN 978-81-7622-271-6

Saharan P, Duhan JS, Gahlawat SK, Surekha (2012) Antioxidant potential of various extracts of stem of Thuja orientalis: in vitro study. Intern J Appl Biol Pharm Technol 3:264-271

Saharan P, Sadh PK, Duhan JS (2017) Comparative assessment of effect of fermentation on phenolics, flavonoids and free radical scavenging activity of commonly used cereals. Biocatal Agric Biotechnol 12:236-240. https://doi.org/10.1016/j.bcab.2017.10.013

Saini JK, Saini R, Tewari L (2014) Lignocellulosic agriculture wastes as biomass feedstocks for second-generation bioethanol production: concepts and recent developments. 3. Biotech. https://doi.org/10.1007/ s13205-014-0246-5

Saravanan V, Vijayakumar S (2014) Production of biosurfactant by Pseudomonas aeruginosa PB3A using agro-industrial wastes as a carbon source. Malays J Microbiol 10(1):57-62

Sharanappa A, Wani KS, Pallavi P (2011) Bioprocessing of food industrial waste for a-amylase production by solid state fermentation. Intern J Adv Biotechnol Res 2:473-480

Sindiri MK, Machavarapu M, Vangalapati M (2013) Alfa-amylase production and purification using fermented orange peel in solid state fermentation by Aspergillus niger. Ind J Appl Res 3:49-51

Singh S, Genitha I (2014) Extraction of antioxidants from fruit peels and its utilization in paneer. J Food Process Technol 5:7

Singhania RR, Patel AK, Soccol CR, Pandey A (2009) Recent advances in solidstate fermentation. Biochem Engin J 44:13-18

Siqueira F, Martos E, Silva R, Dias E (2011) Cultivation of Pleurotus sajor-caju on banana stalk and Bahia grass based substrates. Hortic Bras 29:199-204

Sodhi HK, Sharma K, Gupta JK, Soni SK (2005) Production of a thermostable a-amylase from Bacillus sp. PS-7 by solid-state fermentation and its synergistic use in the hydrolysis of malt starch for alcohol production. Process Biochem 40:525-534

Steinkraus KH (1983) Handbook of indigenous fermented foods. M Dekker Inc New York

Suganthi R, Benazir JF, Santhi R, Kumar RV, Hari A, Meenakshi N, Nidhiya KA, Kavitha G, Lakshmi R (2011) Amylase production by Aspergillus niger under solid state fermentation using agro-industrial wastes. Intern J Eng Sci Technol 3:1756-1763 
Sukan A, Roy I, Keshavarz T (2014) Agro-industrial waste materials as substrates for the production of poly (3-hydroxybutyric acid). J Biomater Nanobiotechnol 5:229-240

Thakur SA, Nemade SN, Sharanappa A (2015) Solid state fermentation of overheated soybean meal (waste) for production of protease using Aspergillus oryzae. Inten J Innov Res Sci Eng Technol 4:18456-18461

Thomas L, Larroche C, Pandey A (2013) Current developments in solid-state fermentation. Biochem Eng J 81:146-161

Topakas E, Kalogeris E, Kekos D, Macris BJ, Christakopoulos P (2004) Production of phenolics from corn cabs by coupling enzymic treatment and solid state fermentation. Eng Life Sci 4(3):283-286

Tripathi KD (2008) Antimicrobial drugs. Essentials of medical pharmacology, 6th edn. Jaycee Brothers Medical Publishers Ltd, New Delhi, p 710

Van Veen AG, Graham DCW, Steinkraus KH (1968) Fermented peanut press cake. Cereal Sci Today 13:96-99

Vastrad BM, Neelagund SE (2011a) Optimization and production of neomycin from different agro industrial wastes in solid state fermentation. Intern J Pharma Sci Drug Res 3:104-111

Vastrad BM, Neelagund SE (2011b) Optimization of process parameters for rifamycin b production under solid state fermentation from Amycolatopsis mediterranean MTCC 14. Intern J Curr Pharm Res 4:101-108
Vidhyalakshmi R, Vallinachiyar C, Radhika R (2012) Production of xanthan from agro-industrial waste. J Adv Sci Res 3:56-59

Wang L, Yang ST (2007) Solid state fermentation and its applications. In bioprocessing for value-added products from renewable resources: new technologies and applications. Elsevier, Amsterdam, pp 465-489

Weshahy AA, Rao VA (2012) Potato peel as a source of important phytochemical antioxidant nutraceuticals and their role in human health - a review. Phytochemicals as nutraceuticals - Global approaches to their role in nutrition and health pp 207-224

Win MM, Azizah AH, Bablishah BS, Farooq A, Mandumpal SC, Mohd PS (2011) Phenolic compounds and antioxidant activity of peanut's skin, hull, raw kernel and roasted kernel flour. Pak J Bot 43:1635-1642

Yang SS, Swei WJ (1996) Cultural condition and oxytetracycline production by Streptomyces rimosus in solid state fermentation of corn cob. World J Microbiol Biotechnol 12:43-46

Zafar S (2014) Waste management, waste-to-energy. https://www.bioenergyconsult.com/tag/waste-to-energy

\section{Submit your manuscript to a SpringerOpen ${ }^{\circ}$ journal and benefit from:}

- Convenient online submission

- Rigorous peer review

- Open access: articles freely available online

- High visibility within the field

- Retaining the copyright to your article

Submit your next manuscript at springeropen.com 